\title{
Vitamin D Status in Japanese Adults: Relationship of Serum 25-Hydroxyvitamin D with Simultaneously Measured Dietary Vitamin D Intake and Ultraviolet Ray Exposure
}

\author{
Keiko Asakura ${ }^{1, *} \mathbb{*}$, Norihito Etoh ${ }^{2}$, Haruhiko Imamura ${ }^{1}(\mathbb{})$, Takehiro Michikawa ${ }^{1}(\mathbb{D}$, \\ Takahiro Nakamura ${ }^{1}$, Yuki Takeda ${ }^{1}$, Sachie Mori ${ }^{1}$ and Yuji Nishiwaki ${ }^{1}$ \\ 1 Department of Environmental and Occupational Health, School of Medicine, Toho University, 5-21-16, \\ Omori-Nishi, Ota-ku, Tokyo \#143-8540, Japan; haruhiko.imamura@med.toho-u.ac.jp (H.I.); \\ takehiro.michikawa@med.toho-u.ac.jp (T.M.); takahiro.nakamura@med.toho-u.ac.jp (T.N.); \\ md18014t@st.toho-u.jp (Y.T.); ksachie82@gmail.com (S.M.); yuuji.nishiwaki@med.toho-u.ac.jp (Y.N.) \\ 2 Department of Biomedical Engineering, School of Engineering, Tokai University, 143 Shimokasuya, Isehara, \\ Kanagawa \#259-1193, Japan; norihito@tsc.u-tokai.ac.jp \\ * Correspondence: JZF01334@nifty.ne.jp; Tel.: +81-3-3762-4151
}

Received: 17 February 2020; Accepted: 10 March 2020; Published: 11 March 2020

check for updates

\begin{abstract}
Vitamin D insufficiency/deficiency is prevalent worldwide. We investigated the effect of vitamin D intake and ultraviolet ray (UV) exposure on serum vitamin D concentration in Japan. A total of 107 healthy adult participants were recruited from Hokkaido $\left(43^{\circ} \mathrm{N}\right)$ and Kumamoto $\left(33^{\circ} \mathrm{N}\right)$ prefectures. All participants undertook surveys in both summer and winter. Serum 25-hydroxyvitamin $\mathrm{D}\left(25(\mathrm{OH}) \mathrm{D}_{3}\right)$ was examined, and vitamin $\mathrm{D}$ intake was assessed with a diet history questionnaire. UV exposure was measured with a wearable UV dosimeter. Regression analysis was performed to investigate the relationship between these factors, with covariates such as sun avoidance behavior. The prevalence of vitamin D insufficiency (serum $25(\mathrm{OH}) \mathrm{D}_{3} ; 12 \mathrm{ng} / \mathrm{mL}(30 \mathrm{nmol} / \mathrm{L}) \leq$ and $<20 \mathrm{ng} / \mathrm{mL}$ $(50 \mathrm{nmol} / \mathrm{L})) /$ deficiency $(<12 \mathrm{ng} / \mathrm{mL})$ was $47.7 \%$ in summer and $82.2 \%$ in winter. UV exposure time was short in Kumamoto (the urban area), at $11.6 \mathrm{~min}$ in summer and $14.9 \mathrm{~min}$ in winter. In Hokkaido (the rural area), UV exposure time was $58.3 \mathrm{~min}$ in summer and $22.5 \mathrm{~min}$ in winter. Vitamin D intake was significantly associated with serum $25(\mathrm{OH}) \mathrm{D}_{3}$, and a $1 \mu \mathrm{g} / 1000 \mathrm{kcal}$ increase in intake was necessary to increase $25(\mathrm{OH}) \mathrm{D}_{3}$ by $0.88 \mathrm{ng} / \mathrm{mL}$ in summer and by $1.7 \mathrm{ng} / \mathrm{mL}$ in winter. UV exposure time was significantly associated with serum $25(\mathrm{OH}) \mathrm{D}_{3}$ in summer, and a 10 min increase in UV exposure time was necessary to increase $25(\mathrm{OH}) \mathrm{D}_{3}$ by $0.47 \mathrm{ng} / \mathrm{mL}$. Although consideration of personal occupation and lifestyle is necessary, most Japanese may need to increase both vitamin D intake and UV exposure.
\end{abstract}

Keywords: vitamin D; ultraviolet ray exposure; dietary intake; quantitative relationship

\section{Introduction}

The fat-soluble vitamin $\mathrm{D}$ has two sources in humans-dietary intake and synthesis in the skin following exposure to ultraviolet B (UVB) radiation with wavelengths from 290 to $320 \mathrm{~nm}$ [1]. Vitamin D has important functions in bone health [1], and several recent studies have investigated other positive health effects, including the prevention of cancer [2] and cardiovascular disease [3]. Findings for these non-skeletal outcomes remain inconclusive, however, and current dietary recommendations for vitamin $\mathrm{D}$ have been designed to maintain serum 25 -hydroxyvitamin $\mathrm{D}(25(\mathrm{OH}) \mathrm{D})$ at concentrations sufficient to maintain healthy bones [1]. 
Despite the importance of vitamin D, deficiency (serum $25(\mathrm{OH}) \mathrm{D} ;<12 \mathrm{ng} / \mathrm{mL}(30 \mathrm{nmol} / \mathrm{L})$ ) and insufficiency $(12 \mathrm{ng} / \mathrm{mL} \leq$ and $<20 \mathrm{ng} / \mathrm{mL}(50 \mathrm{nmol} / \mathrm{L}))$ have been reported worldwide [4,5]. They are also prevalent in Japan: one study reported the proportion of pregnant Japanese women with low $(<20$ $\mathrm{ng} / \mathrm{mL}$ ) serum 25(OH)D was $89.8 \%$ in April (Spring) and $47.8 \%$ in October (Autumn) [6], while another group reported a similar rate of $41.6 \%$ in April and May among Japanese workers, mostly men [7].

While several countries have established dietary reference values for vitamin D intake to avoid deficiency [8], these efforts have been challenging. The lack of UV measurement tools has hampered efforts to estimate the effect of UV exposure on vitamin D status in the body, and reference values in several northern countries were established assuming that UVB exposure was minimal. Examples include the North American Institute of Medicine (IOM) [1] and Nordic Nutrition Recommendations working group [9], which recommends values of 10-20 $\mu \mathrm{g} /$ day. In Japan, a reference value called "adequate intake (AI)" has been established [10], assuming that a proportion of vitamin D comes from cutaneous synthesis. This value is set when there is insufficient evidence to establish firmer indexes, such as estimated average requirements and recommended dietary allowance. AI for Japanese adults of $5.5 \mu \mathrm{g} /$ day is much lower than that of other countries [10]. The Japanese Dietary Reference Intakes (DRI) indicate the need for more information, particularly about UV exposure [10].

A recent device, the UV Dosimeter Badge, quantitatively measures personal UV exposure. The utility and reliability of this device have been confirmed [11]. Here, we used the UV Dosimeter Badge to simultaneously measure serum $25(\mathrm{OH}) \mathrm{D}$, vitamin D intake and UV exposure, and estimate the respective contributions of vitamin D intake and UV exposure to serum vitamin D concentration in Japan, a middle-latitude country.

\section{Materials and Methods}

\subsection{Study Design and Participants}

We recruited apparently healthy adult volunteers aged 20 to 69 years from two areas of Japan, in cooperation with local governments. The northern area was Shakotan Town, Hokkaido prefecture, located at 43 degrees north. Shakotan is located in a rural area with approximately 2000 residents, and fishery and tourism are the major industries. In 2018, max/min temperature in summer and winter was $34.0 / 4.4^{\circ} \mathrm{C}$ and $13.2 /-16.9^{\circ} \mathrm{C}$, respectively. It frequently snows in the town in winter. The southern area was Kumamoto City, in Kumamoto prefecture at 33 degrees north, an urban area with approximately 740,000 residents and tertiary industry as the major activity. In the same year, max/min temperature in summer and winter was $38.1 / 15.7^{\circ} \mathrm{C}$ and $24.0 /-5.2{ }^{\circ} \mathrm{C}$, respectively. The monthly means of $\max / \mathrm{min}$ UV index in Hokkaido and Kumamoto in 2018 were 0.7 (December)/5.4 (July) and 1.9 (January and December)/8.4 (August), respectively. The target number of participants from each area was 60 (120 in total), with 12 participants (six men and six women) recruited from each of five 10-year age groups (20-29, 30-39, 40-49, 50-59, and 60-69 years) to adjust for the effects of age and sex. This number was decided mostly on the basis of feasibility, considering the burden of the surveys, population and age structure of the survey area, and limited number of UV Dosimeter Badges. Inclusion criteria were (1) age 20-69 years, (2) living or working in one of the study areas, (3) ability to answer questionnaires written in Japanese, and (4) skin color of East Asians. We excluded pregnant and lactating women to avoid the influence of temporal change in dietary habits. In total, 120 subjects participated.

\subsection{Measurement Schedule}

The survey schedule and items are shown in Figure 1. The study was performed in accordance with the Declaration of Helsinki and was approved by the Ethics Committee of the Faculty of Medicine, Toho University (approval no. A18035_A17031, July 10, 2017). In each area, the surveys were performed twice, at the end of summer and at the end of winter to catch the highest and lowest serum vitamin $D$ values (Figure 1, (1)). The Japan Meteorological Agency defines summer as being from June to August, 
and winter from December to February. Regarding people living in Japan, there is no previous work showing in which month vitamin D synthesis in the skin starts to affect serum $25(\mathrm{OH}) \mathrm{D}$ concentration.

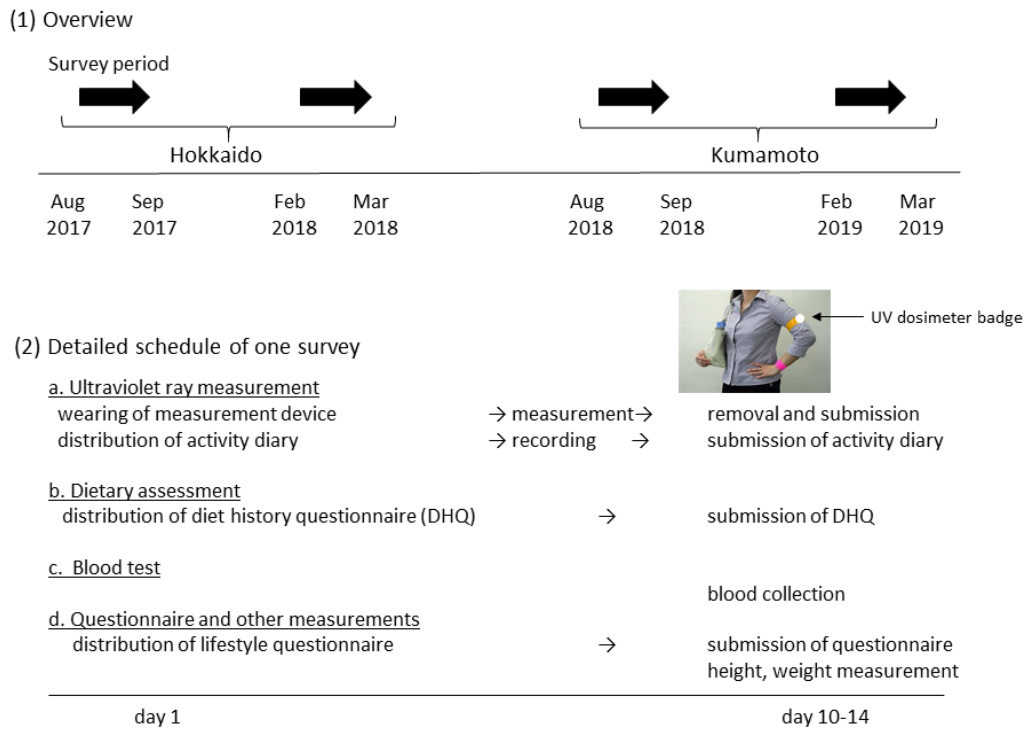

Figure 1. Survey schedule.

Participants were asked to participate in both surveys by local government officials in health-related departments orally, by telephone, or by email. After obtaining written informed consent by the researchers, a UV measurement device, two questionnaires, and an activity diary were distributed to the participants on the first survey day. They wore the device for 10-14 days, and kept the activity diary with a focus on factors relating to UV exposure (clothing, sunscreen use, duration of outdoor activity). They also completed the dietary assessment and lifestyle questionnaires during this period. After the UV measurement period, the participants visited the survey site to return the UV measurement device and submit the questionnaires. At this time, blood specimens were collected and body height/weight were measured.

\subsection{Ultraviolet Ray Exposure Measurement}

The UV Dosimeter Badge (Scienterra Limited, Otago, New Zealand), a round, button-like electric device of $36 \mathrm{~mm}$ diameter, $12 \mathrm{~mm}$ thick, and 26 grams, was used to measure exposure to UV of shorter wavelengths (UVB) [11]. Each participant wore it on the upper arm of their nondominant hand with an arm band. The badge measures UVB power $\left(\mu \mathrm{W} / \mathrm{cm}^{2}\right)$ irradiated on its sensor every two seconds from sunrise to sunset. Stored data is offloaded to a computer using a docking cradle, which communicates with the badge through a high-speed optical interface. For this study, UV exposure time (minutes/day) was calculated as cumulative time (minutes) in which we observed UVB irradiation on the badge across all measurement days divided by the number of measurement days. Crude UV exposure energy $\left(\mathrm{J} / \mathrm{cm}^{2} /\right.$ day) was calculated as the time-integrated value of UVB-irradiated power at each moment during the day. For this analysis, UV exposure energy was adjusted by body surface area, irradiated body site, clothing and sunscreen use per day. Adjusted UV exposure energy (J/day) for each participant was calculated (Figure 2). Total body surface area $\left(\mathrm{cm}^{2}\right)$ was calculated according to Kurazumi's formula [12], and body proportion factor for each body site was set as reported by Lund and Browder [13]. UV power adjustment by irradiated body site [14] and by hat [15] was performed based on previous studies. If sunscreen was used, UV power was multiplied by 0.9 , albeit there is scarce evidence that sunscreen decreases serum 25(OH)D concentration [16]. We used 0.9 in consideration of the likely use of sunscreen with a high sun protection factor (SPF). Information about the weather during the survey period was not utilized, because this information was already reflected in the measured UV exposure energy. 
1) Crude exposure energy $\left(\mathrm{J} / \mathrm{cm}^{2} /\right.$ day) was calculated for each survey day.

2) Total body surface area $\left(\mathrm{cm}^{2}\right)$ was calculated according to Kurazumi's formula (12).

3) We assumed that body sites which were possibly irradiated by UV in daily life (target sites) were the face/neck, lower arms, hands, and lower legs. Area of each target site was calculated by multiplying the total body surface area by a body proportion factor for each site ( 0.055 for face/neck, 0.05 for hands, 0.06 for lower arms, and 0.14 for lower legs) as reported by Lund and Browder (13).

4) Since irradiated UV power differs among target sites, coefficients for power adjustment were included in the calculations. Namely, when UV power irradiating the upper arm (position of the Dosimeter Badge) is regarded as one, the coefficients are 0.48 for the face/neck, 1 for the hands, 1 for the lower arms, and 0.29 for the lower legs (14).

5) Use of sunshade clothing/tools was adjusted per day. If a hat was worn, the irradiated UV power on the face/neck was multiplied by 0.58 in summer or 0.85 in winter (15). When long-sleeve clothes were worn, power on the arms was regarded as zero, and it was also assumed that gloves completely cut power on the hands.

6) Use of sunscreen was adjusted per day. If sunscreen was used, UV power was multiplied by 0.9. There is no evidence for this coefficient; rather, there is scarce evidence that sunscreen decreases serum $25(\mathrm{OH}) \mathrm{D}$ concentration (16). We used 0.9 in consideration of the likely use of sunscreen with a high-sun protection factor (SPF).

**The adjusted UV exposure energy on a target area for a day $(\mathrm{J} / \mathrm{day})^{* *}$

$=$ crude exposure energy on that day $\left(\mathrm{J} / \mathrm{cm}^{2} /\right.$ day $)$

$\mathrm{x}\left[\right.$ \{total body surface area $\left(\mathrm{cm}^{2}\right) \times$ factors for the target site $] \times$ coefficient for UV power adjustment $x$ coefficient for sunshade clothing/tools use] $x$ coefficient for sunscreen use

7) The adjusted UV exposure energies of the four target areas were summed each day.

8) Finally, the adjusted UV exposure energy of all survey days was summed, then divided by the number of measurement days.

Figure 2. Calculation of adjusted UV exposure energy (J/day). Reference numbers correspond to those in the text.

\subsection{Dietary Assessment}

Dietary intake of vitamin D was assessed using a comprehensive self-administered diet history questionnaire (DHQ), a 22-page semi-quantitative questionnaire that assessed habitual dietary intake during the month preceding implementation of the survey. Details and results of validation studies of the DHQ have been reported elsewhere [17-19]. For instance, Shiraishi et al reported the validity of the DHQ for estimating vitamin D intake in pregnant Japanese women. Pearson's correlation coefficients between dietary vitamin $\mathrm{D}$ intakes and serum $25(\mathrm{OH}) \mathrm{D}$ concentration were $0.304(p=0.001)$ in all subjects and $0.371(p=0.001)$ in those without nausea in winter, the season in which serum $25(\mathrm{OH}) \mathrm{D}$ concentrations are less likely to be affected by sunlight. Submitted DHQs were checked by trained research staff immediately after collection, who followed up with the respondent directly over unclear points. Estimates of daily intake of foods, energy, and nutrients were calculated based on the Standard Tables of Food Composition in Japan [20]. Before analysis, vitamin D intake was energy-adjusted by the density method, wherein daily vitamin D intake was calculated as the amount $(\mu \mathrm{g})$ per $1000 \mathrm{kcal}$ of daily energy intake [21]. In Japan, supplement use of vitamin D is uncommon, given that only $10 \%-30 \%$ of people are estimated to use supplements of any type [22-24]. Vitamin D fortification of foods is rare.

\subsection{Blood Tests}

Serum $25(\mathrm{OH})$ D was measured by liquid chromatography-tandem mass spectrometry (LC-MS/MS) at LSI Medience Corporation (Tokyo, Japan). The company used '6PLUS1 Multilevel Serum Calibrator Set 25-OH-Vitamin D3/D2' and 'MassCheck 25-OH-Vitamin D3/D2 Serum Control, Bi-Level (I+II)' for calibration and validation of the measurements in accordance with the company's application notes. These materials are supplied by Chromsystems (Gräfelfing, Germany) and are verified by National Institute of Standards and Technology's standards. Interassay CV for $25(\mathrm{OH}) \mathrm{D}_{3}$ measurement was $4.9 \%$. Serum concentrations of $25(\mathrm{OH}) \mathrm{D}_{2}$ and $25(\mathrm{OH}) \mathrm{D}_{3}$ were measured, but only $25(\mathrm{OH}) \mathrm{D}_{3}$ values were used as index because all values of $25(\mathrm{OH}) \mathrm{D}_{2}$ were below the lower limit of measurement. In 
accordance with the DRI for calcium and vitamin D in the US and Canada [1], a serum concentration of $25(\mathrm{OH}) \mathrm{D}_{3}$ of $\geq 20 \mathrm{ng} / \mathrm{mL}(50 \mathrm{nmol} / \mathrm{L}, 1 \mathrm{ng} / \mathrm{mL}=2.5 \mathrm{nmol} / \mathrm{L})$ was considered to indicate sufficiency of vitamin $\mathrm{D}$ in the body. Similarly, serum $25(\mathrm{OH}) \mathrm{D}_{3}<12 \mathrm{ng} / \mathrm{mL}(30 \mathrm{nmol} / \mathrm{L})$ was defined as vitamin $\mathrm{D}$ deficiency, while a value between these cutoffs $\left(12 \mathrm{ng} / \mathrm{mL} \leq 25(\mathrm{OH}) \mathrm{D}_{3}<20 \mathrm{ng} / \mathrm{mL}\right)$ was considered the range of vitamin $\mathrm{D}$ insufficiency. In addition to $25(\mathrm{OH}) \mathrm{D}$, the intact parathyroid hormone $(\mathrm{PTH})$ was measured by electrochemiluminescence immunoassay (ECLIA) as an index of serum calcium status and bone metabolism.

\subsection{Questionnaire and Other Measurements}

Information on participants' backgrounds and lifestyle factors, particularly those related to UV exposure, was obtained by a self-administered questionnaire. Skin type was based on the Fitzpatrick phototyping scale [25], and physical activity in summer was based on the International Physical Activity Questionnaire (IPAQ) [26,27].

Body height and weight were measured to the nearest $0.1 \mathrm{~cm}$ and $0.1 \mathrm{~kg}$, respectively, in light clothing and no shoes. BMI was calculated as body weight in kilograms divided by the square of body height in meters.

\subsection{Statistical Analysis}

A total of 107 participants who completed all surveys in summer and winter were included. Characteristics were summarized by study area and sex. The relationship of serum $25(\mathrm{OH}) \mathrm{D}_{3}$ with dietary vitamin D intake and UV exposure was then depicted in scatter plots, with data from Hokkaido and Kumamoto shown in the same plot by season. Finally, we examined the relationship by linear regression analysis. In the models, serum $25(\mathrm{OH}) \mathrm{D}_{3}$ was a dependent variable, with dietary vitamin D intake and UV exposure (either time (model $1_{\text {time }}, 2_{\text {time }}$ ) or energy (model $\left.1_{\text {energy }}, 2_{\text {energy }}\right)$ ) simultaneously included as independent variables. Sex (reference: men) and study area (reference: Hokkaido) were adjusted in models $1_{\text {time }}$ and $1_{\text {energy. }}$. Age was excluded from models $1_{\text {time }}$ and $1_{\text {energy }}$ to avoid over-adjustment, because it was positively and significantly associated with vitamin D intake and UV exposure. Other covariates were selected from factors possibly related to serum vitamin D concentration and/or cutaneous vitamin D synthesis [1,28]. In model 2 time, age, smoking, skin type, sunscreen use (nonuser/user), sunshade clothing/tools use (nonuser/user (any or all of hat, gloves, and parasol)), and physical activity (summer only) were included, in addition to the variables included in the model $1_{\text {time. }}$ In model $2_{\text {energy, }}$ age, smoking, skin type, and physical activity (summer only) were included, in addition to those included in the model $2_{\text {time }}$, because UV exposure energy had already been adjusted by clothing and sunscreen use. All analyses were performed with SAS version 9.4 (SAS Institute, Cary, NC, USA). Statistical tests were two-sided, and $p$ values of $<0.05$ were considered statistically significant.

\section{Results}

Participants' characteristics are summarized in Table 1. All participants completed the surveys both in summer and winter. Average serum $25(\mathrm{OH}) \mathrm{D}_{3}$ among all subjects $(n=107)$ was $21.1 \mathrm{ng} / \mathrm{mL}$ in summer and $14.6 \mathrm{ng} / \mathrm{mL}$ in winter, and was marginally or significantly higher in Hokkaido (t test, $p=0.07$ in both summer and winter) and in men ( $p<0.001$ in summer, $p=0.08$ in winter). The prevalence of vitamin D insufficiency/deficiency was $47.7 \%$ in summer and $82.2 \%$ in winter. The greatest contributor to total vitamin D intake was fish, which accounted for $70.9 \%$ of total intake both in summer and winter. The second contributor was eggs $(12.0 \%$ in summer and $12.3 \%$ in winter), followed in order by confectionaries $(4.4 \%$ and $4.7 \%)$ and mushrooms ( $4.0 \%$ and $4.5 \%$, respectively).

The relationships between serum $25(\mathrm{OH}) \mathrm{D}_{3}$ and dietary vitamin $\mathrm{D}$ intake, and between serum $25(\mathrm{OH}) \mathrm{D}_{3}$ and UV exposure time/energy in summer and winter are shown in scatter plots in Figure 3. All regression lines rose to the right. Distributions of UV exposure, particularly UV exposure energy, were narrower in winter. 
Table 1. Characteristics of participants (total participants: $n=107$ ).

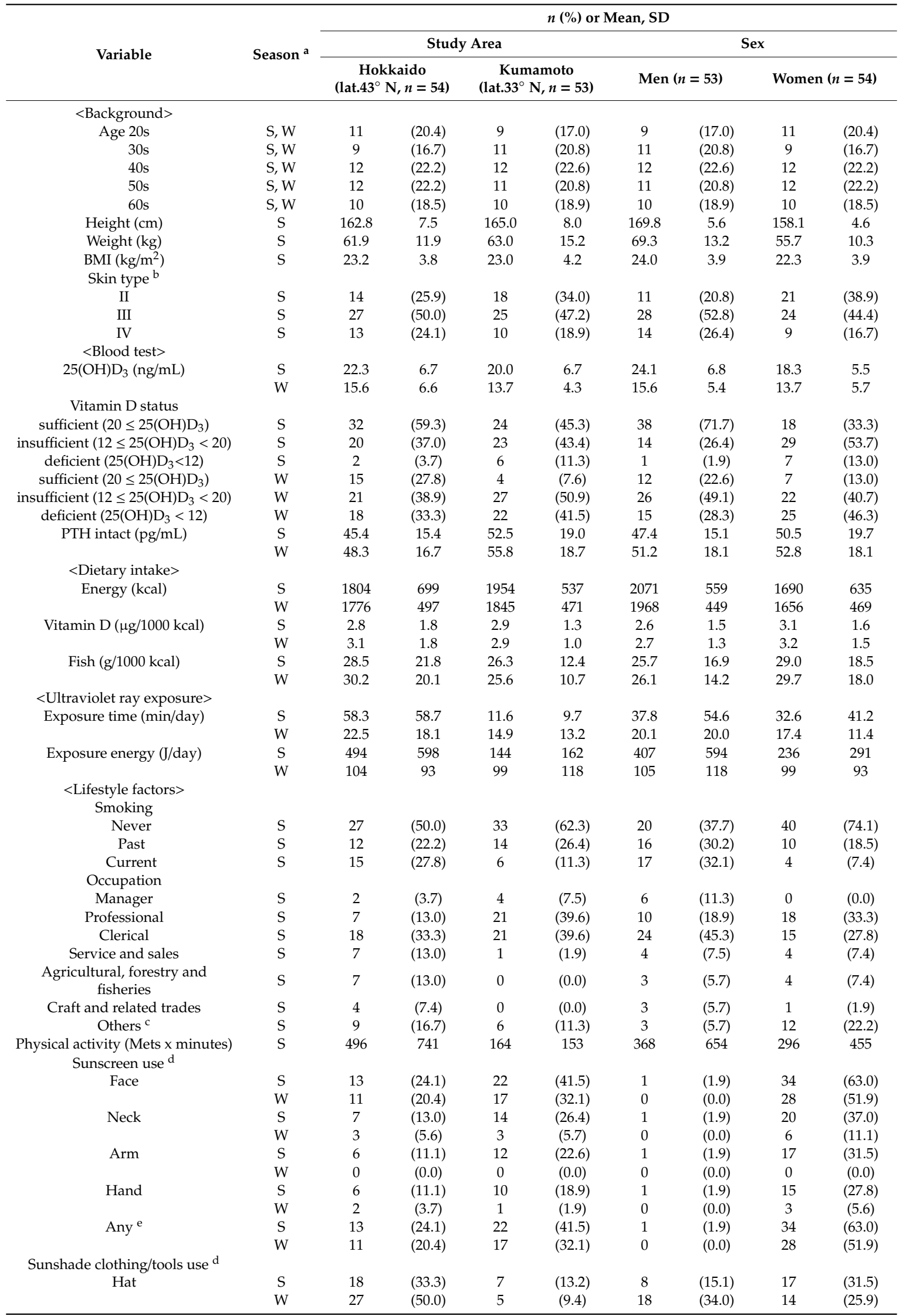


Table 1. Cont.

\begin{tabular}{|c|c|c|c|c|c|c|c|c|c|}
\hline \multirow{3}{*}{ Variable } & \multirow{3}{*}{ Season $^{a}$} & \multicolumn{8}{|c|}{$n(\%)$ or Mean, SD } \\
\hline & & \multicolumn{4}{|c|}{ Study Area } & \multicolumn{4}{|c|}{ Sex } \\
\hline & & \multicolumn{2}{|c|}{$\begin{array}{c}\text { Hokkaido } \\
\left(\text { lat. } 43^{\circ} \mathrm{N}, n=54\right)\end{array}$} & \multicolumn{2}{|c|}{$\begin{array}{c}\text { Kumamoto } \\
(\text { lat.33 } \mathrm{N}, n=53)\end{array}$} & \multicolumn{2}{|c|}{ Men $(n=53)$} & \multicolumn{2}{|c|}{ Women $(n=54)$} \\
\hline \multirow[t]{2}{*}{ Parasol } & S & 6 & $(11.1)$ & 22 & $(41.5)$ & 3 & (5.7) & 25 & (46.3) \\
\hline & $\mathrm{W}$ & 2 & $(3.7)$ & 0 & $(0.0)$ & 1 & (1.9) & 1 & (1.9) \\
\hline Long sleeves & $S$ & 13 & $(24.1)$ & 10 & $(18.9)$ & 9 & $(17.0)$ & 14 & (25.9) \\
\hline Gloves & W & 35 & $(64.9)$ & 14 & $(26.4)$ & 25 & $(47.2)$ & 24 & $(44.5)$ \\
\hline \multirow[t]{2}{*}{ Combination ${ }^{\mathrm{f}}$} & $S$ & 24 & $(44.4)$ & 24 & $(45.3)$ & 12 & $(22.6)$ & 36 & (66.7) \\
\hline & W & 37 & $(68.5)$ & 17 & (32.1) & 28 & $(52.8)$ & 26 & $(48.2)$ \\
\hline
\end{tabular}

Body mass index (BMI); latitude (lat); parathyroid hormone (PTH); 25-hydroxyvitamin $\mathrm{D}_{3}\left(25(\mathrm{OH}) \mathrm{D}_{3}\right)$; ${ }^{\text {a Season }}$ in which the survey was performed. Summer (S), winter (W); ${ }^{b}$ Fitzpatrick skin type was self-reported. The classification was made by erythema and tanning reactions to first exposure to sunlight in summer. II: usually burn, tan less than average, III: sometimes mildly burn, tan about average, IV: rarely burn, tan more than average; ' ${ }^{c}$ The "Other" category of occupation included housewives, retirees, and so on; ${ }^{\mathrm{d}}$ Multiple answers allowed; " The "Any" category of sunscreen use includes all sunscreen users irrespective of application site; ${ }^{\mathrm{f}}$ The "Combination" category of sunshade clothing/tools use includes users who used any or all of hat, parasol, and gloves.
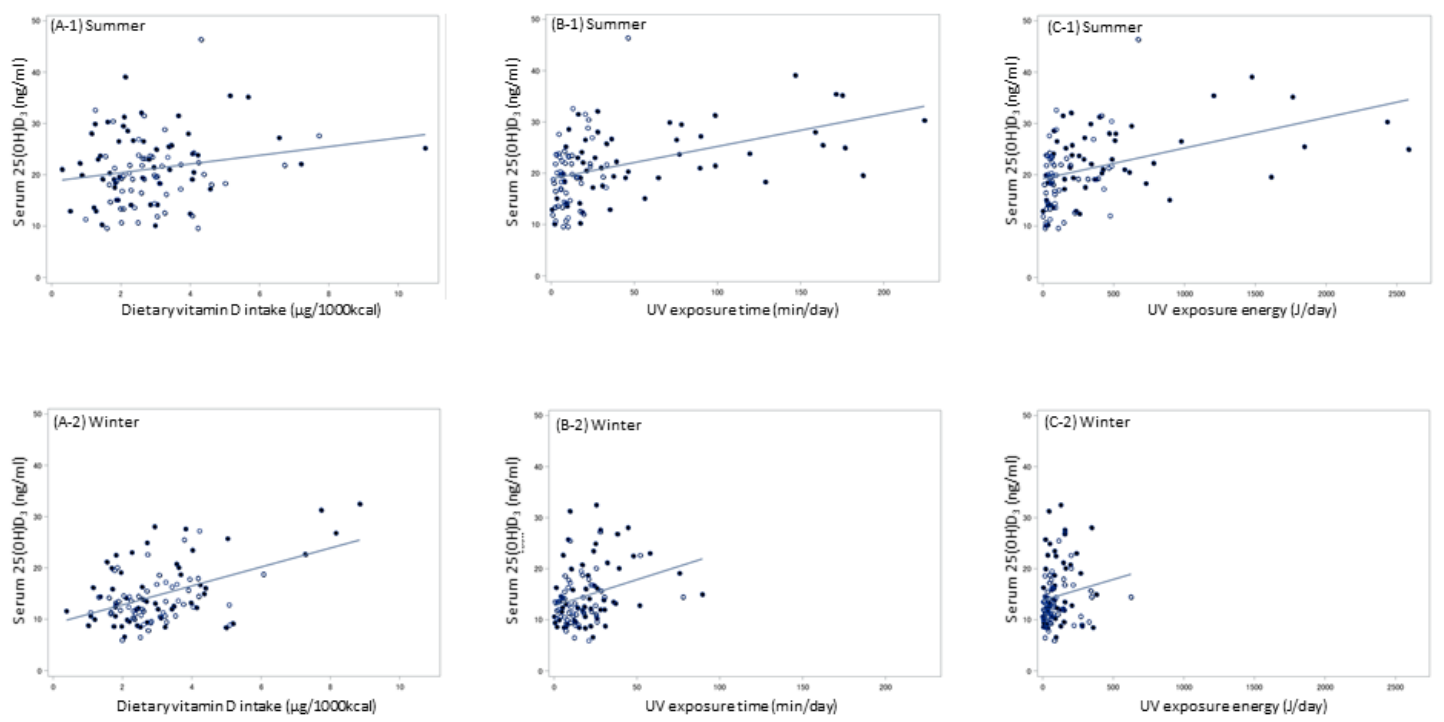

Figure 3. Relationship of serum $25(\mathrm{OH}) \mathrm{D}_{3}$ with dietary vitamin D intake and UV exposure; (A) dietary vitamin D intake $(\mu \mathrm{g} / 1000 \mathrm{kcal})$ and serum $25(\mathrm{OH}) \mathrm{D}_{3}$ concentration $(\mathrm{ng} / \mathrm{mL}) ;($ B) UV exposure time (min/day) and serum $25(\mathrm{OH}) \mathrm{D}_{3}$ concentration $(\mathrm{ng} / \mathrm{mL}) ;(\mathrm{C}) \mathrm{UV}$ exposure energy $(\mathrm{J} /$ day) and serum $25(\mathrm{OH}) \mathrm{D}_{3}$ concentration $(\mathrm{ng} / \mathrm{mL})$; Symbols: • Hokkaido (northern Japan), $\bigcirc$ Kumamoto (southern Japan).

Linear regression analyses are shown in Tables 2 and 3. In both summer and winter, vitamin $\mathrm{D}$ intake, UV exposure time and sex were significantly associated with serum $25(\mathrm{OH}) \mathrm{D}_{3}$ in Model $1_{\text {time }}$ (Table 2). In contrast, area was not associated with serum $25(\mathrm{OH}) \mathrm{D}_{3}$. In Model $2_{\text {time, }}$, no added covariate except age was associated with serum $25(\mathrm{OH}) \mathrm{D}_{3}$. UV exposure time was not significantly associated with serum $25(\mathrm{OH}) \mathrm{D}_{3}$ in winter in Model 2 time, but became marginal and the regression coefficient changed to 0.057 (95\% CI, -0.003 to 0.117 ) when age was eliminated. In Model $2_{\text {time, }}$ a $1 \mu \mathrm{g} / 1000 \mathrm{kcal}$ increase in vitamin D intake was necessary to increase serum $25(\mathrm{OH}) \mathrm{D}_{3}$ by $0.88 \mathrm{ng} / \mathrm{mL}$ in summer and $1.7 \mathrm{ng} / \mathrm{mL}$ in winter. Similarly, a $10 \mathrm{~min}$ increase in UV exposure time was necessary to increase serum $25(\mathrm{OH}) \mathrm{D}_{3}$ by $0.47 \mathrm{ng} / \mathrm{mL}$ in summer and $0.41 \mathrm{ng} / \mathrm{mL}$ in winter. Results were similar when UV exposure energy was used in the models (Table 3). The difference in results was the non-significant relationship between serum $25(\mathrm{OH}) \mathrm{D}_{3}$ and UV exposure energy in Model $1_{\text {energy }}$ in winter. Results were similar when the coefficient for sunscreen use (0.9) was not used to adjust for UV exposure energy. 
Table 2. Relationship between dietary vitamin D intake, UV exposure time and serum $25(\mathrm{OH}) \mathrm{D}_{3}$ concentration by season among Japanese adults $(n=107)$.

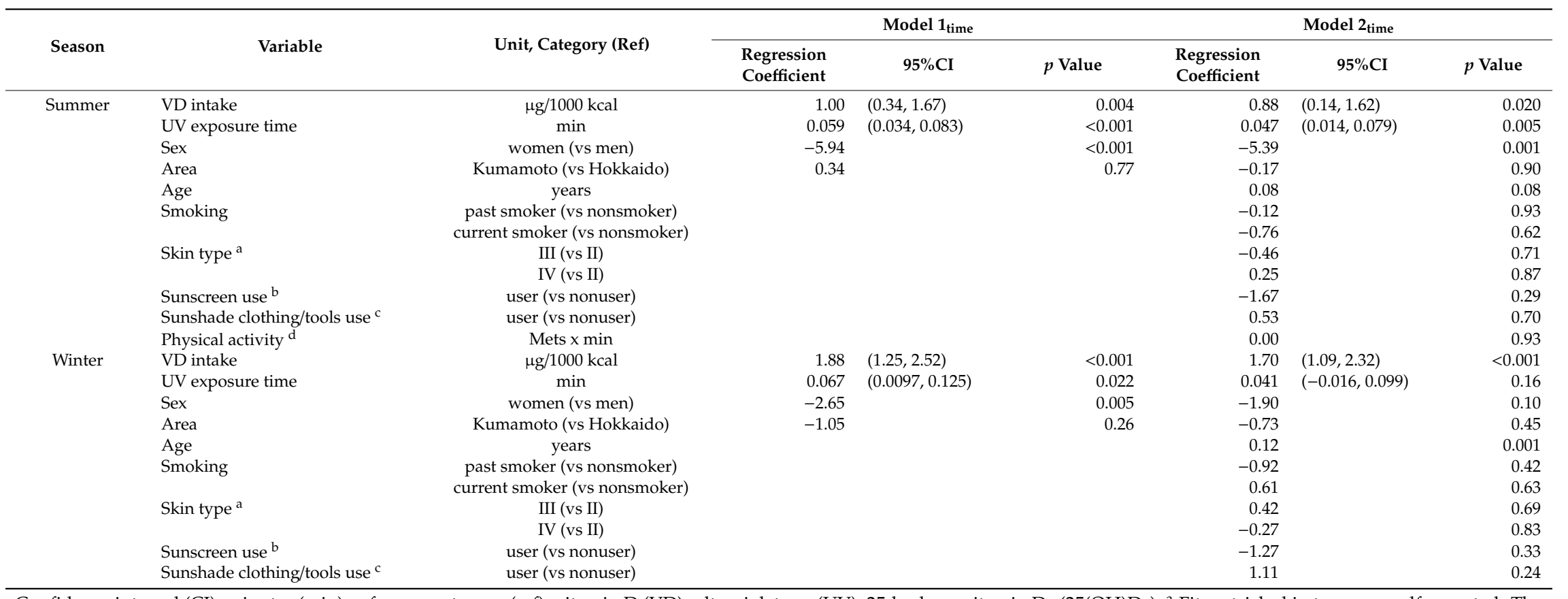

Confidence interval (CI); minutes ( $\mathrm{min})$; reference category (ref); vitamin D (VD); ultraviolet ray (UV); 25 -hydroxyvitamin $\mathrm{D}_{3}\left(25(\mathrm{OH}) \mathrm{D}_{3}\right)$; ${ }^{\text {a }}$ Fitzpatrick skin type was self-reported. The classification was made by erythema and tanning reactions to first exposure to sunlight in summer. II: usually burn, tan less than average, III: sometimes mildly burn, tan about average, IV: rarely burn, tan more than average; ${ }^{b}$ Nonuser means those who did not use sunscreen at all. Those who used sunscreen on any body surface were considered users; ${ }^{c}$ Those who used any or all of hat, parasol, and gloves. The others were considered nonusers; ${ }^{\mathrm{d}}$ Physical activity level was estimated by the International Physical Activity Questionnaire (IPAQ) only in summer. 
Table 3. Relationship between dietary vitamin D intake, $\mathrm{UV}$ exposure energy and serum $25(\mathrm{OH}) \mathrm{D}_{3}$ concentration by season among Japanese adults $(n=107)$.

\begin{tabular}{|c|c|c|c|c|c|c|c|c|}
\hline \multirow[b]{2}{*}{ Season } & \multirow[b]{2}{*}{ Variable } & \multirow{2}{*}{ Unit, Category (Ref) } & \multicolumn{3}{|c|}{ Model 1 $1_{\text {energy }}$} & \multicolumn{3}{|c|}{ Model 2 energy } \\
\hline & & & $\begin{array}{l}\text { Regression } \\
\text { Coefficient }\end{array}$ & $95 \% \mathrm{CI}$ & $p$ Value & $\begin{array}{l}\text { Regression } \\
\text { Coefficient }\end{array}$ & $95 \% \mathrm{CI}$ & $p$ Value \\
\hline \multirow{10}{*}{ Summer } & VD intake & $\mu \mathrm{g} / 1000 \mathrm{kcal}$ & 1.10 & $(0.41,1.79)$ & 0.002 & 0.81 & $(0.083,1.55)$ & 0.029 \\
\hline & UV exposure energy a & $\mathrm{J} /$ day & 0.004 & $(0.0020,0.0069)$ & 0.001 & 0.004 & $(0.001,0.007)$ & 0.012 \\
\hline & Sex & women (vs men) & -5.52 & & $<0.001$ & -5.80 & & $<0.001$ \\
\hline & Area & Kumamoto (vs Hokkaido) & -0.85 & & 0.46 & -1.41 & & 0.23 \\
\hline & Age & years & & & & 0.12 & & 0.005 \\
\hline & Smoking & past smoker (vs nonsmoker) & & & & 0.02 & & 0.99 \\
\hline & & current smoker (vs nonsmoker) & & & & -1.01 & & 0.51 \\
\hline & Skin type ${ }^{b}$ & III (vs II) & & & & -0.51 & & 0.69 \\
\hline & & IV (vs II) & & & & 0.15 & & 0.93 \\
\hline & Physical activity ${ }^{c}$ & Mets $x$ min & & & & 0.00 & & 0.90 \\
\hline \multirow[t]{9}{*}{ Winter } & VD intake & $\mu \mathrm{g} / 1000 \mathrm{kcal}$ & 1.94 & $(1.29,2.58)$ & $<0.001$ & 1.75 & $(1.13,2.36)$ & $<0.001$ \\
\hline & UV exposure energy & $\mathrm{J} /$ day & 0.005 & $(-0.004,0.013)$ & 0.29 & 0.004 & $(-0.005,0.012)$ & 0.37 \\
\hline & Sex $1+2$ & women (vs men) & -2.83 & & 0.003 & -2.66 & & 0.007 \\
\hline & Area & Kumamoto (vs Hokkaido) & -1.53 & & 0.10 & -1.58 & & 0.08 \\
\hline & Age & years & & & & 0.14 & & $<0.001$ \\
\hline & Smoking & past smoker (vs nonsmoker) & & & & -0.72 & & 0.53 \\
\hline & & current smoker (vs nonsmoker) & & & & 0.61 & & 0.63 \\
\hline & Skin type ${ }^{b}$ & III (vs II) & & & & 0.59 & & 0.57 \\
\hline & & IV (vs II) & & & & -0.08 & & 0.95 \\
\hline
\end{tabular}

Confidence interval (CI); minutes (min); reference category (ref); vitamin D (VD); ultraviolet ray (UV); 25 -hydroxyvitamin $\mathrm{D}_{3}\left(25(\mathrm{OH}) \mathrm{D}_{3}\right)$; ${ }^{\text {a }} \mathrm{UV}$ exposure energy adjusted by exposed body surface area, irradiated body site, as well as sunscreen and sunshade clothing/tools use; ${ }^{b}$ Fitzpatrick skin type was self-reported. The classification was made by erythema and tanning reactions to first exposure to sunlight in summer; II: usually burn, tan less than average, III: sometimes mildly burn, tan about average, IV: rarely burn, tan more than average; ${ }^{c}$ Physical activity level was estimated by the International Physical Activity Questionnaire (IPAQ) only in summer. 


\section{Discussion}

This study is the first to measure UV exposure (both time and energy) and vitamin D intake, and to investigate the relationship between them simultaneously; this study is also the first to perform standardized measurements in both summer and winter in both northern and southern Japan. In particular, this study is the first to compare the influence of time of UV exposure with energy of exposure and serum $25(\mathrm{OH}) \mathrm{D}$ levels, with both being objectively measured via electronic dosimeters. Results showed that the prevalence of vitamin D insufficiency/deficiency was high, and was rather higher in (southern) Kumamoto than (northern) Hokkaido, suggesting that the effect of lifestyle factors, such as dietary habits and length of outdoor activity, had greater influence on vitamin D status in the body than this difference in latitude.

Vitamin D intake did not considerably differ between the two areas, at around $3 \mu \mathrm{g} / 1000 \mathrm{kcal}$ $(6 \mu \mathrm{g} / 2000 \mathrm{kcal}$ : approximate of daily intake). This intake is the same as the AI (5.5 $\mu \mathrm{g} / \mathrm{day})$ in the Japanese DRI [10]. Given the high prevalence of vitamin D insufficiency in Japan, however, these findings indicate that most Japanese should consume more vitamin D, even in summer. A new version of the Japanese DRI (version 2020) is now being adopted; in this, the AI is raised from 5.5 to $8.5 \mu \mathrm{g} /$ day for adults. Close observation is required to determine the effect of this change.

Perhaps surprisingly, UV exposure time was longer and energy was stronger among participants in Hokkaido than Kumamoto, particularly in summer (Table 1). Most participants in Kumamoto were office workers. Their mean UV exposure time of $11.6 \mathrm{~min}$ in summer and $14.9 \mathrm{~min}$ in winter suggests that exposure primarily occurred when out of the office, such as in short walks during commuting, going out for lunch, or shopping. Since $71.0 \%$ of employed Japanese work in tertiary industries such as retailing, food service and financial businesses [29], the lifestyle observed in Kumamoto is likely representative of Japanese living in cities. Longer outdoor activity would be preferable for people with short UV exposure time. While an appropriate length of UV exposure requires further discussion, the average UV exposure time we observed in Kumamoto may act as a reference. In addition, this study is the first to estimate and adjust UV exposure energy by exposed body surface area, irradiated body site, and use of sunscreen/clothing. In winter, UV exposure energy was not significantly associated with serum $25(\mathrm{OH}) \mathrm{D}_{3}$. This non-significant relationship may have been due to the low energy itself and its narrow distribution, and the importance of vitamin $\mathrm{D}$ intake would appear to be greater in winter. In addition, although we asked the participants to wear the dosimeter over the top of their clothing, it was more difficult to measure and adjust UV exposure power in winter, because most participants wore jackets and cold protectors.

Female participants and those of a younger age were significantly associated with lower serum $25(\mathrm{OH}) \mathrm{D}_{3}$. Women tended to avoid tanning, using sunscreen and sunshade clothing, and this might have caused lower UV exposure energy in women, particularly in summer. Regarding age, given findings that increases in serum $25(\mathrm{OH}) \mathrm{D}$ by vitamin $\mathrm{D}$ intake do not vary with age up to at least 80 years [30,31], whereas the capacity to produce vitamin $\mathrm{D}_{3}$ in skin decreases with aging [32], it is difficult to assume that serum $25(\mathrm{OH}) \mathrm{D}_{3}$ physiologically increases with age. The higher serum $25(\mathrm{OH}) \mathrm{D}_{3}$ in older participants appears to be due to external factors, namely a higher intake of fish as a major vitamin D source and longer UV exposure (Supplementary Table S1). Fish intake in the participants in their twenties was $19.8 \mathrm{~g} / 1000 \mathrm{kcal}$ in summer and $25.1 \mathrm{~g} / 1000 \mathrm{kcal}$ in winter, versus respective values in those in their sixties of 33.8 and $29.6 \mathrm{~g} / 1000 \mathrm{kcal}$. Further, UV exposure time was $16.1 \mathrm{~min}$ in summer and $15.0 \mathrm{~min}$ in winter in those in their twenties, versus 68.4 and $26.4 \mathrm{~min}$ in those in their sixties, respectively. Since half of the participants in their sixties were housewives or post-retirement, they may have had more time to perform outside activities.

Sunscreen and sunshade clothing/tools use also showed no association with $25(\mathrm{OH}) \mathrm{D}_{3}$ in the multivariate models (Table 2). Most sunscreen users were women, and sunshade tool use substantially differed between men and women. As sex was significantly associated with serum $25(\mathrm{OH}) \mathrm{D}_{3}$, we were unable to rule out sex as a possible confounding factor. In addition, physical activity was not associated with serum $25(\mathrm{OH}) \mathrm{D}_{3}$ in summer. Some previous studies did report such an association [33,34], but 
this may likely have been a surrogate marker of UV exposure. There are some past studies suggesting a relationship between body mass index (BMI) and serum vitamin D concentration [35]. However, we did not include BMI in the statistical models, because we observed no relationship between them.

As shown in Figure 3 and Tables 2 and 3, we assumed that the relationship of serum $25(\mathrm{OH}) \mathrm{D}_{3}$ with vitamin D intake and UV exposure was linear. Based on this assumption, the regression coefficients shown in Tables 2 and 3 indicated the effect of the amount of dietary vitamin D intake and UV exposure to serum $25(\mathrm{OH}) \mathrm{D}_{3}$. However, some studies have suggested that these relationships are not linear [1]. Aloia et al. reported that the response of serum 25(OH)D to $1 \mu \mathrm{g}$ of vitamin $\mathrm{D}_{3}$ intake was inversely dependent on the basal 25(OH)D concentration [36]. Similarly, Olds et al. suggested that the relationship between sun exposure and serum $25(\mathrm{OH}) \mathrm{D}$ level was curvilinear [37]. Interestingly, excess previtamin $D_{3}$ and vitamin $D_{3}$ is destroyed by sunlight [38]. Therefore, the effect of dietary vitamin $\mathrm{D}$ intake and UV exposure on people with vitamin D insufficiency may be larger than the coefficients in this study. This homeostatic mechanism might also explain the smaller difference in serum $25(\mathrm{OH}) \mathrm{D}_{3}$ concentration in summer between Hokkaido and Kumamoto compared with the larger difference in UV exposure.

A few studies have investigated internal vitamin D status with quantitative measurement of UV exposure. Callegari et al. reported that personal sun exposure measured by the same Dosimeter Badge as used here was significantly associated with serum $25(\mathrm{OH}) \mathrm{D}_{3}$, but did not report the length of UV exposure and did not include vitamin D intake in their regression models [39]. Scragg et al. also used this dosimeter, but also did not investigate vitamin D intake [40]. O'Sullivan et al. estimated the daily ambient UVB dose for each participant in their study by using irradiated UV energy at various geographical points in Ireland and the residential address of the participants, and reported a relationship between it and serum $25(\mathrm{OH}) \mathrm{D}$ concentration [41]. Their estimation method differed from ours, which directly measured UV energy on the participants' arms.

Several limitations of this study should be mentioned. First, the participant number was small and sampling was not random. Accordingly, the participants were likely to have been more health-conscious than the general population. Since the burden of the survey was heavy, random sampling was not feasible. Although the target number for recruitment was decided mostly based on feasibility, it seemed that the number of participants was appropriate to detect differences of behavior affecting serum vitamin D status, because the difference was large. For example, to detect whether differences in UV exposure time between participants with and without sufficient serum vitamin D were significant using a two-sample $t$ test, a total of 90 subjects in summer and 81 subjects in winter were required, with an alpha equal to 0.05 and statistical power of 0.80 (calculated by proc power procedure of SAS). Second, the occupation of the participants substantially differed between Hokkaido and Kumamoto. This caused a difference in UV exposure, and may have masked the effect of latitude. Nevertheless, our results are consistent with other studies showing that latitude alone does not always predict average serum vitamin D level in a population [42]. Third, since we adopted self-reported dietary assessment, misreporting was possible. However, the questionnaire was validated and responses were checked carefully, likely minimizing measurement errors. Fourth, this study is the first to adjust UV exposure by the area of the body exposed and sun avoidance behavior, and the coefficients used in the adjustment require further consideration. Finally, as described above, the relationship of serum $25(\mathrm{OH}) \mathrm{D}_{3}$ with UV exposure and vitamin D intake may not be linear. This study is the first to show these regression coefficients, i.e., effect sizes for these relationships, but they should be interpreted with care.

\section{Conclusions}

Vitamin D insufficiency/deficiency was prevalent in a Japanese population, even in a mid-latitude area. Both vitamin D intake and UV exposure affected vitamin D status in the body. Although consideration for personal occupation and lifestyle is necessary, most Japanese may need to increase both vitamin D intake and UV exposure. 
Supplementary Materials: The following are available online at http://www.mdpi.com/2072-6643/12/3/743/s1, Table S1: Differences between age groups in vitamin D intake, food intake, and UV exposure.

Author Contributions: Conceptualization, K.A. and Y.N.; methodology, K.A. and N.E.; formal analysis, K.A. and N.E.; investigation (data collection), K.A., H.I., T.M., T.N., Y.T., S.M., and Y.N.; writing-original draft preparation, K.A.; writing-review and editing, K.A., N.E., H.I., T.M., T.N., Y.T., S.M., and Y.N.; supervision, Y.N.; project administration, K.A.; funding acquisition, Y.N. All authors have read and agreed to the published version of the manuscript.

Funding: This research was funded by The Uehara Memorial Foundation, and by the Research Complex Program; Wellbeing Research Campus: creating new values through technological and social innovation. There were no grant numbers.

Acknowledgments: We thank the city officials of Shakotan Town and Kumamoto City who supported the recruitment and survey for this study. We also thank the survey staff at Toho University: Yu Tsuyusaki, Junko Hanakawa, Satsue Nagahama, Emi Yamazaki, Fukumi Ibusuki, Kazuya Nogi, and Juichiro Higashi.

Conflicts of Interest: The authors declare no conflict of interest.

\section{References}

1. Institute of Medicine (US). Committee to Review Dietary Reference Intakes for Vitamin D and Calcium. In Dietary Reference Intakes for Calcium and Vitamin D; Ross, A.C., Taylor, C.L., Yaktine, A.L., Del Valle, H.B., Eds.; The National Academies Press: Washington, DC, USA, 2011.

2. Zhang, Y.; Fang, F.; Tang, J.; Jia, L.; Feng, Y.; Xu, P.; Faramand, A. Association between vitamin D supplementation and mortality: Systematic review and meta-analysis. BMJ 2019, 366, 14673. [CrossRef]

3. Orkaby, A.R.; Djousse, L.; Manson, J.E. Vitamin D supplements and prevention of cardiovascular disease. Curr. Opin. Cardiol. 2019, 34, 700-705. [CrossRef]

4. Holick, M.F. The vitamin D deficiency pandemic: Approaches for diagnosis, treatment and prevention. Rev. Endocr. Metab. Disord. 2017, 18, 153-165. [CrossRef] [PubMed]

5. van Schoor, N.M.; Lips, P. Worldwide vitamin D status. Best Pract. Res. Clin. Endocrinol. Metab. 2011, 25, 671-680. [CrossRef] [PubMed]

6. Kanatani, K.T.; Nakayama, T.; Adachi, Y.; Hamazaki, K.; Onishi, K.; Konishi, Y.; Kawanishi, Y.; Go, T.; Sato, K.; Kurozawa, Y.; et al. High frequency of vitamin D deficiency in current pregnant Japanese women associated with UV avoidance and hypo-vitamin D diet. PLoS ONE 2019, 14, e0213264. [CrossRef] [PubMed]

7. Mizoue, T.; Kochi, T.; Akter, S.; Eguchi, M.; Kurotani, K.; Tsuruoka, H.; Kuwahara, K.; Ito, R.; Kabe, I.; Nanri, A. Low serum 25-hydroxyvitamin D concentrations are associated with increased likelihood of having depressive symptoms among Japanese workers. J. Nutr. 2015, 145, 541-546. [CrossRef] [PubMed]

8. Cashman, K.D.; Kiely, M. Recommended dietary intakes for vitamin D: Where do they come from, what do they achieve and how can we meet them? J. Hum. Nutr. Diet. 2014, 27, 434-442. [CrossRef]

9. Nordic Council of Ministers. Nordic Nutrition Recommendations 2012 5th Edition. Available online: http://norden.diva-portal.org/smash/get/diva2:704251/FULLTEXT01.pdf (accessed on 1 November 2019).

10. Ministry of Health, Labour and Welfare. Dietary Reference Intakes for Japanese, 2015; Daiichi Shuppan Publishing Co., Ltd.: Tokyo, Japan, 2014.

11. Grandahl, K.; Mortensen, O.S.; Sherman, D.Z.; Køster, B.; Lund, P.A.; Ibler, K.S.; Eriksen, P. Solar UV exposure among outdoor workers in Denmark measured with personal UV-B dosimeters: Technical and practical feasibility. Biomed. Eng. Online 2017, 16, 119. [CrossRef]

12. Kurazumi, Y.; Horikoshi, T.; Tsuchikawa, T.; Matsubara, N. The body surface area for Japanese. Jpn. J. Biometeor. 1994, 31, 5-29.

13. Lund, C.C.; Browder, N.C. The estimation of areas of burns. Surg. Gynecol. Obstet. 1944, 79, 352-358.

14. Eto, N.; Asakura, K.; Nishiwaki, Y. Relationships between solar ultraviolet exposure levels at different sites around the body. Toho J. Med. 2019, in press.

15. Backes, C.; Religi, A.; Moccozet, L.; Vuilleumier, L.; Vernez, D.; Bulliard, J.L. Facial exposure to ultraviolet radiation: Predicted sun protection effectiveness of various hat styles. Photodermatol. Photoimmunol. Photomed. 2018, 34, 330-337. [CrossRef] [PubMed]

16. Neale, R.E.; Khan, S.R.; Lucas, R.M.; Waterhouse, M.; Whiteman, D.C.; Olsen, C.M. The effect of sunscreen on vitamin D: A review. Br. J. Dermatol. 2019, 18, 907-915. [CrossRef] [PubMed] 
17. Kobayashi, S.; Murakami, K.; Sasaki, S.; Okubo, H.; Hirota, N.; Notsu, A.; Fukui, M.; Date, C. Comparison of relative validity of food group intakes estimated by comprehensive and brief-type self-administered diet history questionnaires against 16 d dietary records in Japanese adults. Public Health Nutr. 2011, 14, 1200-1211. [CrossRef]

18. Kobayashi, S.; Honda, S.; Murakami, K.; Sasaki, S.; Okubo, H.; Hirota, N.; Notsu, A.; Fukui, M.; Date, C. Both comprehensive and brief self-administered diet history questionnaires satisfactorily rank nutrient intakes in Japanese adults. J. Epidemiol. 2012, 22, 151-159. [CrossRef] [PubMed]

19. Shiraishi, M.; Haruna, M.; Matsuzaki, M.; Murayama, R.; Kitanaka, S.; Sasaki, S. Validity of a self-administered diet history questionnaire for estimating vitamin D intakes of Japanese pregnant women. Matern. Child Nutr. 2015, 11, 525-536. [CrossRef] [PubMed]

20. The Council for Science and Technology. Standard Tables of Food Composition in Japan, Fifth Revised and Enlarged edition-2010; Official Gazette Cooperation: Tokyo, Japan, 2010.

21. Willett, W.C.; Howe, G.R.; Kushi, L.H. Adjustment for total energy intake in epidemiologic studies. Am. J. Clin. Nutr. 1997, 65 (Suppl. 4), 1220S-1228S. [CrossRef]

22. Kobayashi, E.; Sato, Y.; Umegaki, K.; Chiba, T. The Prevalence of Dietary Supplement Use among College Students: A Nationwide Survey in Japan. Nutrients 2017, 9, 1250. [CrossRef]

23. Kobayashi, E.; Nishijima, C.; Sato, Y.; Umegaki, K.; Chiba, T. The Prevalence of Dietary Supplement Use Among Elementary, Junior High, and High School Students: A Nationwide Survey in Japan. Nutrients 2018, 10, 1176. [CrossRef]

24. Masumoto, S.; Sato, M.; Maeno, T.; Ichinohe, Y. Factors associated with the use of dietary supplements and over-the-counter medications in Japanese elderly patients. BMC Fam. Pract. 2018, 19, 20. [CrossRef]

25. Fitzpatrick, T.B. The validity and practicality of sun-reactive skin types I through VI. Arch. Dermatol. 1988, 124, 869-871. [CrossRef] [PubMed]

26. Murase, N.; Katsumura, T.; Ueda, C.; Inoue, S.; Shimomitsu, T. Validity and reliability of Japanese version of International Physical Activity Questionnaire. J. Health Welf. Stat. 2002, 49, 1-9.

27. Craig, C.L.; Marshall, A.L.; Sjostrom, M.; Bauman, A.E.; Booth, M.L.; Ainsworth, B.E.; Pratt, M.; Ekelund, U.; Yngve, A.; Sallis, J.F.; et al. International physical activity questionnaire: 12-country reliability and validity. Med. Sci. Sports Exerc. 2003, 35, 1381-1395. [CrossRef] [PubMed]

28. Jiang, C.Q.; Chan, Y.H.; Xu, L.; Jin, Y.L.; Zhu, T.; Zhang, W.S.; Cheng, K.K.; Lam, T.H. Smoking and serum vitamin D in older Chinese people: Cross-sectional analysis based on the Guangzhou Biobank Cohort Study. BMJ Open 2016, 6, e010946. [CrossRef]

29. Statistics Bureau, Ministry of Internal Affairs and Communications, Japan. Statistical Handbook of Japan, 2019. Available online: https://www.stat.go.jp/english/data/handbook/index.html (accessed on 1 November 2019).

30. Cashman, K.D.; Hill, T.R.; Lucey, A.J.; Taylor, N.; Seamans, K.M.; Muldowney, S.; Fitzgerald, A.P.; Flynn, A.; Barnes, M.S.; Horigan, G.; et al. Estimation of the dietary requirement for vitamin D in healthy adults. Am. J. Clin. Nutr. 2008, 88, 1535-1542. [CrossRef]

31. Cashman, K.D.; Wallace, J.M.; Horigan, G.; Hill, T.R.; Barnes, M.S.; Lucey, A.J.; Bonham, M.P.; Taylor, N.; Duffy, E.M.; Seamans, K.; et al. Estimation of the dietary requirement for vitamin D in free-living adults >=64 y of age. Am. J. Clin. Nutr. 2009, 89, 1366-1374. [CrossRef]

32. MacLaughlin, J.; Holick, M.F. Aging decreases the capacity of human skin to produce vitamin D3. J. Clin. Investig. 1985, 76, 1536-1538. [CrossRef]

33. Cheng, T.Y.; Millen, A.E.; Wactawski-Wende, J.; Beresford, S.A.; LaCroix, A.Z.; Zheng, Y.; Goodman, G.E.; Thornquist, M.D.; Neuhouser, M.L. Vitamin D intake determines vitamin d status of postmenopausal women, particularly those with limited sun exposure. J. Nutr. 2014, 144, 681-689. [CrossRef]

34. Ohta, H.; Kuroda, T.; Onoe, Y.; Orito, S.; Ohara, M.; Kume, M.; Harada, A.; Tsugawa, N.; Okano, T.; Sasaki, S. The impact of lifestyle factors on serum 25-hydroxyvitamin D levels: A cross-sectional study in Japanese women aged 19-25 years. J. Bone Miner Metab. 2009, 27, 682-688. [CrossRef]

35. Hyppönen, E.; Boucher, B.J. Adiposity, Vitamin D Requirements, and Clinical Implications for Obesity-Related Metabolic Abnormalities. Nutr. Rev. 2018, 76, 678-692. [CrossRef]

36. Aloia, J.F.; Patel, M.; Dimaano, R.; Li-Ng, M.; Talwar, S.A.; Mikhail, M.; Pollack, S.; Yeh, J.K. Vitamin D intake to attain a desired serum 25-hydroxyvitamin D concentration. Am. J. Clin. Nutr. 2008, 87, 1952-1958. [CrossRef] [PubMed] 
37. Olds, W.J.; McKinley, A.R.; Moore, M.R.; Kimlin, M.G. In vitro model of vitamin D3 (cholecalciferol) synthesis by UV radiation: Dose-response relationships. J. Photochem. Photobiol. B 2008, 93, 88-93. [CrossRef] [PubMed]

38. Holick, M.F. Vitamin D deficiency. N. Engl. J. Med. 2007, 357, 266-281. [CrossRef] [PubMed]

39. Callegari, E.T.; Garland, S.M.; Gorelik, A.; Reavley, N.J.; Wark, J.D. Predictors and correlates of serum 25-hydroxyvitamin D concentrations in young women: Results from the Safe-D study. Br. J. Nutr. 2017, 118, 263-272. [CrossRef]

40. Scragg, R.K.R.; Stewart, A.W.; McKenzie, R.L.; Reeder, A.I.; Liley, J.B.; Allen, M.W. Sun exposure and 25-hydroxyvitamin D3 levels in a community sample: Quantifying the association with electronic dosimeters. J. Expo. Sci. Environ. Epidemiol. 2017, 27, 471-477. [CrossRef]

41. O'Sullivan, F.; Laird, E.; Kelly, D.; van Geffen, J.; van Weele, M.; McNulty, H.; Hoey, L.; Healy, M.; McCarroll, K.; Cunningham, C.; et al. Ambient UVB dose and sun enjoyment are important predictors of vitamin D status in an older population. J. Nutr. 2017, 147, 858-868. [CrossRef]

42. Kimlin, M.G.; Olds, W.J.; Moore, M.R. Location and vitamin D synthesis: Is the hypothesis validated by geophysical data? J. Photochem. Photobiol. B 2007, 86, 234-239. [CrossRef]

C 2020 by the authors. Licensee MDPI, Basel, Switzerland. This article is an open access article distributed under the terms and conditions of the Creative Commons Attribution (CC BY) license (http://creativecommons.org/licenses/by/4.0/). 